\title{
Alat Pengukur pH Berbasis Arduino
}

\author{
Hanifah Rahmi Fajrin*1, Ummu Zakiyyah², Kuat Supriyadi ${ }^{3}$ \\ ${ }^{1,2}$ Universitas Muhammadiyah Yogyakarta, Indonesia \\ ${ }^{3}$ Rumah Sakit Umum Pendidikan dr. Sardjito Yogyakarta, Indonesia
}

INFO ARTIKEL

Alamat Web Artikel:

https://journal.umy.ac.id/index.php/mt

/article/view/8536

DOI:

https://doi.org/10.18196/mt.010207

Data Artikel:

Diterima:

04 April 2020

Direview:

15 April 2020

Direvisi :

21 April 2020

Disetujui :

30 April 2020

Korespondensi:

hanifah.fajrin@vokasi.umy.ac.id

\begin{abstract}
ABSTRAK
Dalam bidang medis, konsentrasi ion hidrogen sangat mempengaruhi proses metabolisme yang terjadi dalam tubuh karena hampir semua aktivitas enzim dalam tubuh dipengaruhi oleh konsentrasi ion hidrogen. Pengaturan konsentrasi ion hidrogen, dalam beberapa kasus, mirip dengan pengaturan ion lain dalam tubuh, di mana untuk mendapatkan homeostasis, harus ada keseimbangan asupan, produksi, dan sekresi ion hidrogen. Mengukur $\mathrm{pH}$ tubuh dapat dilakukan dengan tes analisis gas darah, ada beberapa faktor yang harus dipertimbangkan dalam tes ini: gelembung udara, antikoagulan, metabolisme, dan suhu. Mengabaikan faktor-faktor itu akan mempengaruhi hasil tes. Tes menggunakan kertas lakmus memiliki keterbatasan pada keakuratan dan kesalahan pembacaan warna dapat terjadi karena sampel berwarna atau feculent. Alat pengukuran berbasis $\mathrm{pH}$ Arduino akan dirancang dalam penelitian ini. Desainnya menggunakan sensor elektroda kaca yang mendeteksi jumlah ion hidrogen dalam larutan modul sensor sebagai pengkondisi sinyal dan modul Arduino untuk mengontrol sistem secara keseluruhan. Pengujian alat dilakukan di laboratorium farmasi dan farmakologi Universitas Muhammadiyah, Yogyakarta dengan membandingkan nilai $\mathrm{pH}$ alat dengan $\mathrm{pH}$ meter di laboratorium. Berdasarkan pengumpulan data yang dilakukan dengan 10 kali pengujian menggunakan larutan buffer dan sampel urin, hasil kesalahan tidak lebih dari $1,5 \%$. Hasilnya masih dalam batas toleransi, yaitu tidak lebih dari $5 \%$.
\end{abstract}

Kata Kunci: Arduino, pH, pH meter

\section{PENDAHULUAN}

Dalam bidang kesehatan skala $\mathrm{pH}$ dapat menggambarkan secara tepat konsentrasi dari ion hidrogen dalam tubuh. Konsentrasi ion hidrogen sangat mempengaruhi proses metabolisme yang berlangsung dalam tubuh karena hampir semua aktifitas enzim dalam tubuh dipengaruhi oleh konsentrasi ion hidrogen dalam tubuh. Tidak mengherankan pengaturan keseimbangan konsentrasi ion hidrogen ini sangat penting dalam kehidupan organisme. Pengaturan konsentrasi ion hidrogen dalam beberapa hal sama dengan pengaturan ion-ion lain dalam tubuh, dimana untuk mencapai homeostasis harus ada keseimbangan antara asupan atau produksi ion hidrogen dan pembuangan ion hidrogen dari tubuh [1]. Berhubungan dengan keseimbangan asam basa tersebut terdapat 2 kelainan ion hidrogen dalam tubuh yang dapat menyebabkan satu di antara dua kelainan utama dalam keseimbangan asam basa, yaitu tubuh mengandung terlalu banyak asam (asidosis) dan mengandung terlalu banyak basa (alkaliosis). Baik asidosis maupun alkaliosis dapat membahayakan nyawa manusia, seperti gangguan ginjal, gangguan irama jantung, dll [2].

Untuk mengetahui $\mathrm{pH}$ pada tubuh dapat dilakukan dengan pengukuran $\mathrm{pH}$ yang umumnya dilakukan dengan dua cara yaitu analisa gas darah dan menggunakan kertas lakmus. Pada pemeriksaan analisa gas darah, untuk mengamati perubahan $\mathrm{pH}$ terdapat beberapa yang faktor yang perlu diperhatikan yaitu gelembung udara, antikoagulan, metabolisme, dan suhu. Jika faktor tersebut tidak diperhatikan maka akan mempengaruhi hasil pemeriksaan analisa gas darah (AGD). Pada pemeriksaan AGD salah satu kesalahan pra-analitik adalah mixing sampel yang tidak sesuai standar. Pengumpulan dan penanganan spesimen darah arteri yang tidak tepat dapat menghasilkan hasil yang keliru [3]. Sementara pada pengujian menggunakan kertas lakmus, mempunyai keterbatasan pada tingkat akurasi pengukuran dan dapat terjadi kesalahan pembacaan warna yang 
disebabkan larutan sampel yang berwarna ataupun keruh [4]. Pengukuran tersebut hanya bersifat kualitatif, hal tersebut dapat menyebabkan hasil yang diperoleh relatif tidak begitu akurat [5].

Selain itu, pengukuran $\mathrm{pH}$ juga dapat dilakukan dengan alat $\mathrm{pH}$ meter. Penelitian untuk menguji $\mathrm{pH}$ dengan alat $\mathrm{pH}$ meter juga telah banyak dilakukan, diantaranya yaitu: penelitian yang dilakukan oleh Bayu Noorulil dan Ratna Adil pada penelitiannya yang berjudul "Rancang Bangun Model Mekanik Alat untuk Mengukur Kadar Keasaman Susu Cair, Sari Buah dan Soft Drink" tersebut masih terdapat kekurangan alat yaitu alat belum dapat bekerja maksimal pada saat pengujian, dari 10 kali pengujian didapatkan sebanyak 7 kali sistem berhasil bekerja dan 3 kali sistem gagal. Sehingga diperoleh $70 \%$ sistem telah bekerja sesuai yang diharapkan [4]. Selanjutnya pada penelitian yang dilakukan oleh Fawaida Silvian dengan judul "PH Meter Digital" masih terdapat kekurangan pada sensor elektroda gelas, dimana sensor memiliki keterbatasan pada range pengukuran $\mathrm{pH}$ dari $\mathrm{pH} \mathrm{0-13} \mathrm{dan} \mathrm{tidak} \mathrm{dapat} \mathrm{mengukur} \mathrm{nilai} \mathrm{Ph}$ lebih dari itu [6]. Penelitian lainnya yaitu oleh Prastyono Eko Pambudi, Edhy utanta dan Mujiman dengan judul "Identifikasi Daging Segar dan Busuk Menggunakan Sensor Warna RGB dan PH Meter Digital" pada penelitian ini perubahan analog to digital converter alat masih menggunakan ADC external dan penampil masih menggunakan seven segment [7]. Selain itu, pada alat $\mathrm{pH}$ meter juga masih terdapat kekurangan pada alat dimana masih menggunakan supply tegangan langsung dari PLN sehingga apabila terjadi pemadaman listrik alat otomatis akan berhenti bekerja. Selain supply tegangan yang masih menggunakan supply dari PLN pada $\mathrm{pH}$ meter juga belum terdapat indikator hasil pengukuran. Oleh karena itu, dibutuhkan alat $p H$ meter portable yang dapat digunakan tanpa supply tegangan dari PLN dan terdapat indikator hasil dari $\mathrm{pH}$.

Dari berbagai macam penelitian yang telah ada tersebut, maka penulis merancang alat pengukur $\mathrm{pH}$ yang akurat dilengkapi indikator baterai dan indikator hasil $\mathrm{pH}$. Dimana alat mendapat supply dari baterai yang dilengkapi display tegangan baterai untuk menampilkan tegangan baterai dan apabila dalam keadaan baterai lemah alat dapat di-charge untuk mengisi kembali tegangan baterai. Selain itu ditambahkan juga indikator hasil pengukuran yaitu asidosis, normal dan alkaliosis yang tertampil pada LCD.

\section{METODE PENELITIAN}

Alat $\mathrm{pH}$ meter digital bekerja dengan dasar sensor berupa elektroda gelas. Pada prinsipnya pengukuran suatu $\mathrm{pH}$ didasarkan pada potensial elektro-kimia yang terjadi antara larutan yang terdapat didalam elektroda gelas (membrane gelas) yang telah diketahui dengan larutan yang terdapat diluar elektroda gelas yang tidak diketahui. Hal ini dikarenakan lapisan tipis dari gelembung kaca akan berinteraksi dengan ion hidrogen yang ukurannya relatif kecil dan aktif, elektroda gelas tersebut akan mengukur potensial elektrokimia dari ion hidrogen atau diistilahkan dengan potential of hydrogen [4]. Dimana setiap larutan akan memberikan bentuk tegangan yang berbeda dari kadar ion-ion yang ada dalam larutan. Hal ini akan ditangkap oleh sensor untuk menghasilkan output berupa sinyal analog [7].

Fungsi elektroda pada $\mathrm{pH}$ meter adalah memonitor perubahan voltase yang disebabkan oleh perubahan aktivitas ion hidrogen $(\mathrm{H}+)$ dalam larutan [8]. Elektroda $\mathrm{pH}$ idealnya berperilaku sebagai sel elektrokimia dan bereaksi terhadap konsentrasi ion $[\mathrm{H}+]$ bahwa setiap larutan akan memberikan bentuk tegangan yang berbeda dari kadar ion-ion yang ada dalam larutan [7]. Dalam elektroda gelas terdapat dua macam elektroda antara lain:

a. Elektroda referensi berfungsi untuk menjaga dan memberikan potensial yang tetap dan tidak dipengaruhi oleh karakteristik.

b. Elektroda pengukur berfungsi sebagai pengukur karena potensialnya berubah-ubah sesuai dengan konsentrasi ion hidrogen dari larutan yang sedang diukur.

Parameter A27 PH Sensor Module adalah modul yang digunakan untuk menguatkan tegangan keluaran dari output sensor yang kecil. Karena tegangan cukup kecil, maka diperlukan pengkondisi sinyal atau penguat tegangan [9]. Cara kerja dari modul ini adalah rangkaian sensor $\mathrm{pH}$ akan membaca nilai $\mathrm{pH}$ dari elektroda sensor berupa sinyal analog. Keluaran dari sensor diterima oleh rangkaian pengkondisian sinyal [10]. Desain ini memungkinkan untuk membantu 
Fajrin, Zakiyyah, Supriyadi

Alat Pengukur pH Berbasis Arduino

pengguna dalam memantau $\mathrm{pH}$ tanpa harus menambahkan sirkuit atau komponen tambahan ke dalam sistem [11].

Arduino merupakan sebuah pengendali mikro single-board yang bersifat open-source, diturunkan dari Wiring platform dan dirancang untuk memudahkan penggunaan elektronik dalam berbagai bidang [12]. Arduino Uno adalah board microcontroller berbasis ATmega328 yang didalamnya terdapat komponen utama yaitu sebuah chip microcontroller dengan jenis AVR dari perusahaan Atmel. Microcontroller itu sendiri adalah chip atau IC (Integrated Circuit) yang bisa diprogram menggunakan komputer [13]. Tujuan menanamkan program pada microcontroller adalah agar rangkaian elektronik dapat membaca input, proses dan output sebuah rangkaian elektronik [14]. Adapun gambar dari board ini dapat dilihat pada Gambar 1di bawah ini:

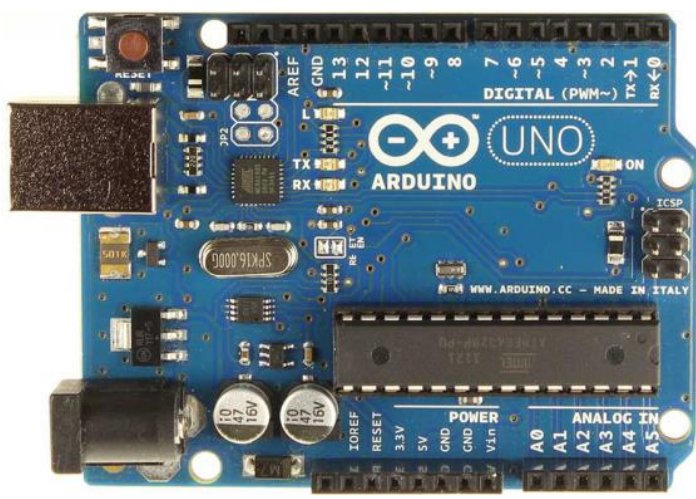

Gambar 1. Board Arduino UNO R3

\section{HASIL DAN PEMBAHASAN}

Langkah dalam penelitian ini diawali dengan identifikasi spesifikasi kebutuhan alat yang akan dibuat, yaitu sebagai berikut: Pertama-tama diperlukan komponen rangkaian catu daya yang berfungsi untuk memberikan supply tegangan dan arus pada rangkaian. Kedua, diperlukan alat pengindra berupa sensor yang peka untuk mendeteksi $\mathrm{pH}$. Ketiga, diperlukan komponen pengendali yang berfungsi untuk mengendalikan alat pendeteksi secara keseluruhan. Dan yang ke empat, diperlukan komponen penampil nilai digital yang sederhana dan informatif.

Dalam konsep perancangannya, diharapkan dapat memenuhi standar pengukuran $\mathrm{pH}$ dengan memperhatikan aspek-aspek yang terkait dalam proses pengukurannya. Rancangan alat dibuat sedemikian rupa agar dalam penggunaannya dapat mempermudah user dalam melakukan pengujian sampel $\mathrm{pH}$ dengan dilengkapi indikator baterai dan indikator hasil nilai $\mathrm{pH}$. Diagram blok alat $\mathrm{pH}$ meter digital yang dirancang ditunjukkan pada Gambar 2 di bawah ini:

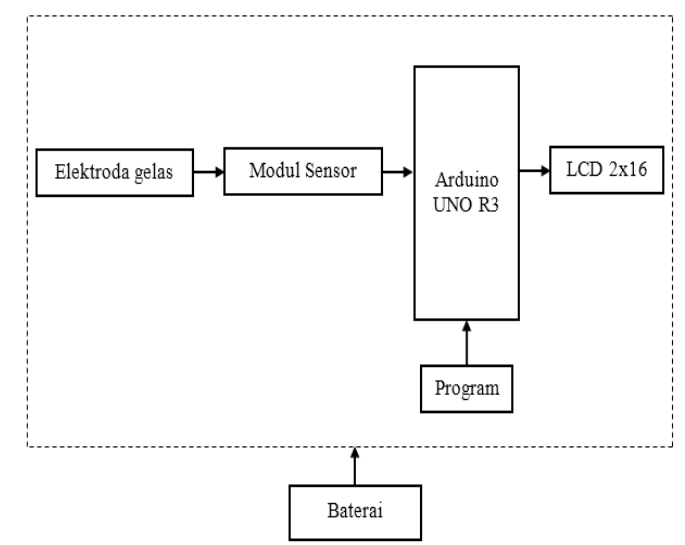

Gambar 2. Blok Diagram Alat 
Fajrin, Zakiyyah, Supriyadi

Alat Pengukur pH Berbasis Arduino

Pada saat alat hidup, semua rangkaian akan mendapat supply tegangan. Selanjutnya sensor elektroda gelas akan mendeteksi pH dari larutan sampel yang kemudian output dari elektroda gelas akan masuk modul sensor untuk dikuatkan. Setelah dikuatkan, output dari modul masuk ke board arduino. Pada board Arduino ini sinyal analog akan dirubah ke digital untuk kemudian ditampilkan pada LCD.

Pengujian alat ini dilakukan di Laboratorium Farmasi dan Farmakologi Fakultas Kedokteran dan Ilmu Kesehatan Universitas Muhammadiyah Yogyakarta. Pada analisa pengujian terdapat parameter yang akan diujikan yaitu nilai $\mathrm{pH}$ yang akan dibandingkan dengan alat $\mathrm{pH}$ meter. Pengujian nilai $\mathrm{pH}$ ini bertujuan untuk memastikan kesesuaian nilai $\mathrm{pH}$ dari alat. Dimana setiap sampel akan dilihat hasilnya pada alat dan pembanding. Pengujian direncanakan dilakukan pengambilan data menggunakan 4 sampel dengan 10 kali pengujian. Sebelum melakukan pengujian pada larutan sampel, sebelumnya alat diuji menggunakan larutan buffer dengan nilai $\mathrm{pH}$ 4,01 dan 6,86 untuk memastikan apakah alat sudah sesuai dengan $\mathrm{pH}$ yang tertera.

Adapun untuk tabel dan analisa hasil pengujian dapat dilihat pada Tabel 1 di bawah ini: Tabel 1. Hasil Pengukuran Larutan Buffer pH 4,01 di Ruang Laboratorium Farmasi dan Farmakologi

\begin{tabular}{|l|l|l|l|l|}
\hline \multirow{2}{*}{ Sampel } & \multirow{2}{*}{ Percobaan } & \multicolumn{2}{|c|}{ Hasil Percobaan } & \multirow{2}{*}{ Selisih } \\
\cline { 3 - 5 } & & $\mathrm{pH}$ meter & Modul Penelitian & \\
\hline \multirow{5}{*}{\begin{tabular}{l} 
Larutan $\begin{array}{l}\text { buffer } \\
4,01\end{array}$ \\
\cline { 2 - 5 }
\end{tabular}} & 1 & 4,09 & 4,03 & 0,06 \\
\cline { 2 - 5 } & 2 & 4,09 & 4,17 & 0,08 \\
\cline { 2 - 5 } & 3 & 4,09 & 4,07 & 0,02 \\
\cline { 2 - 5 } & 4 & 4,09 & 4,19 & 0,1 \\
\cline { 2 - 5 } & 6 & 4,09 & 4,22 & 0,14 \\
\cline { 2 - 5 } & 8 & 4,09 & 4,15 & 0,06 \\
\cline { 2 - 5 } & 9 & 4,09 & 4,09 & 0 \\
\cline { 2 - 5 } & 10 & 4,09 & 4,1 & 0,01 \\
\hline \multicolumn{2}{|l|}{ Rata-rata } & 4,09 & 4,09 & 0,03 \\
\hline
\end{tabular}

Berdasarkan pengambilan data pada larutan buffer 4,01 yang dilakukan sebanyak 10 kali pengujian didapatkan selisih tertinggi yaitu 0,14 pada percobaan ke 5 dan selisih terendah yaitu 0,01 pada percobaan ke 8 . Untuk data hasil pengujian dengan hasil yang baik terdapat pada percobaan 7, 9, 10 karena hasil data yang didapat yaitu 4,09 sama dengan hasil pada alat pembanding. Untuk hasil rata-rata yang didapat pada modul penelitian adalah 4,12 dan alat pembanding 4,09.

Adapun untuk tabel dan analisa hasil pengujian dapat dilihat pada Tabel 2 di bawah ini: Tabel 2. Hasil Pengukuran Larutan Buffer pH 6,86 di Ruang Laboratorium Farmasi dan Farmakologi

\begin{tabular}{|c|l|l|l|l|}
\hline \multirow{3}{*}{ Sampel } & \multirow{2}{*}{ Percobaan } & \multicolumn{2}{|c|}{ Hasil Percobaan } & \multirow{2}{*}{ Selisih } \\
\cline { 3 - 5 } & & $\mathrm{pH}$ meter & $\begin{array}{c}\text { Modul } \\
\text { Penelitian }\end{array}$ & \\
\hline \multirow{3}{*}{$\begin{array}{l}\text { Larutan } \\
\text { buffer 6,86 }\end{array}$} & 1 & 6,88 & 6,89 & 0,01 \\
\cline { 2 - 5 } & 2 & 6,88 & 6,80 & 0,08 \\
\cline { 2 - 5 } & 3 & 6,88 & 6,83 & 0,05 \\
\cline { 2 - 5 } & 4 & 6,88 & 6,75 & 0,13 \\
\hline
\end{tabular}


Fajrin, Zakiyyah, Supriyadi

Alat Pengukur pH Berbasis Arduino

\begin{tabular}{|c|c|c|c|c|}
\hline \multirow[b]{2}{*}{ Sampel } & \multirow[b]{2}{*}{ Percobaan } & \multicolumn{2}{|c|}{ Hasil Percobaan } & \multirow{2}{*}{ Selisih } \\
\hline & & $\begin{array}{c}\mathrm{pH} \\
\text { Meter }\end{array}$ & $\begin{array}{c}\text { Modul } \\
\text { Penelitian }\end{array}$ & \\
\hline \multirow{6}{*}{$\begin{array}{l}\text { Larutan } \\
\text { Buffer } \\
6,86\end{array}$} & 5 & 6,88 & 6,70 & 0,18 \\
\hline & 6 & 6,88 & 6,77 & 0,11 \\
\hline & 7 & 6,88 & 6,75 & 0,13 \\
\hline & 8 & 6,88 & 6,81 & 0,07 \\
\hline & 9 & 6,88 & 6,86 & 0,02 \\
\hline & 10 & 6,88 & 6,89 & 0,01 \\
\hline \multicolumn{2}{|l|}{ Rata-rata } & 6,86 & 6,80 & 0,08 \\
\hline
\end{tabular}

Berdasakan pengambilan data pada larutan buffer 6,86 yang dilakukan sebanyak 10 kali pengujian didapatkan selisih tertinggi yaitu 0,18 pada percobaan ke 5 dan selisih terendah yaitu 0,01 pada percobaan ke 1 dan 10 . Untuk data hasil pengujian dengan hasil yang baik terdapat pada percobaan 1 dan 10 karena hasil data yang didapat yaitu 6,89 berbeda 0,01 dengan hasil pada alat pembanding. Untuk hasil rata-rata yang didapat pada modul TA adalah 6,80 dan alat pembanding 6,88 .

Adapun untuk tabel dan analisa hasil pengujian dapat dilihat pada Tabel 3 di bawah ini: Tabel 3. Hasil Pengukuran Sampel 1 di Ruang Laboratorium Farmasi dan Farmakologi

\begin{tabular}{|c|c|c|c|c|c|}
\hline \multirow[b]{2}{*}{ Sampel } & \multirow[b]{2}{*}{ Percobaan } & \multicolumn{2}{|c|}{ Hasil Percobaan } & \multirow[b]{2}{*}{ Selisih } & \multirow[b]{2}{*}{ Indikator Hasil } \\
\hline & & $\mathrm{pH}$ meter & $\begin{array}{c}\text { Modul } \\
\text { Penelitian }\end{array}$ & & \\
\hline \multirow{10}{*}{$\begin{array}{l}\text { Larutan } \\
\text { urin } 1\end{array}$} & 1 & 6,50 & 6,58 & 0,08 & Normal \\
\hline & 2 & 6,50 & 6,64 & 0,14 & Normal \\
\hline & 3 & 6,50 & 6,42 & 0,08 & Normal \\
\hline & 4 & 6,50 & 6,67 & 0,17 & Normal \\
\hline & 5 & 6,50 & 6,65 & 0,15 & Normal \\
\hline & 6 & 6,50 & 6,60 & 0,1 & Normal \\
\hline & 7 & 6,50 & 6,55 & 0,05 & Normal \\
\hline & 8 & 6,50 & 6,50 & 0 & Normal \\
\hline & 9 & 6,50 & 6,50 & 0 & Normal \\
\hline & 10 & 6,50 & 6,58 & 0,08 & Normal \\
\hline \multicolumn{2}{|l|}{ Rata-rata } & 6,50 & 6,56 & 0,06 & \\
\hline
\end{tabular}

Tabel di atas merupakan hasil pengambilan data pada larutan urin 1 yang dilakukan sebanyak 10 kali pengujian. Untuk nilai yang ditampilkan pada display LCD menunjukkan nilai atau angka keluaran yang tepat sesuai dengan indikasi sebenarnya berdasarkan nilai $\mathrm{pH}$ (normal $=5,5-7$ ). Dari hasil pengujian didapatkan selisih tertinggi yaitu 0,17 pada percobaan 4 dan selisih terendah yaitu 0,05 pada percobaan 7. Untuk data hasil pengujian dengan hasil yang baik terdapat pada percobaan 8 dan 9 karena hasil data yang didapat yaitu 6,50 sama dengan hasil pada alat pembanding. Dari 
Fajrin, Zakiyyah, Supriyadi

Alat Pengukur pH Berbasis Arduino

hasil pengujian 10 kali tersebut didapatkan rata-rata yang pada alat yang dibuat adalah 4,12 dan alat pembanding 4,09.

Adapun untuk tabel dan analisa hasil pengujian dapat dilihat pada Tabel 4 di bawah ini Tabel 4. Hasil Pengukuran Sampel 2 di Ruang Laboratorium Farmasi dan Farmakologi

\begin{tabular}{|c|c|c|c|c|c|}
\hline \multirow[b]{2}{*}{ Sampel } & \multirow[b]{2}{*}{ Percobaan } & \multicolumn{2}{|c|}{ Hasil Percobaan } & \multirow[b]{2}{*}{ Selisih } & \multirow[b]{2}{*}{ Indikator Hasil } \\
\hline & & $\mathrm{pH}$ meter & $\begin{array}{c}\text { Modul } \\
\text { Penelitian }\end{array}$ & & \\
\hline \multirow{10}{*}{$\begin{array}{l}\text { Larutan } \\
\text { urin } 2\end{array}$} & 1 & 5,84 & 5,82 & 0,02 & Normal \\
\hline & 2 & 5,84 & 5,75 & 0,09 & Normal \\
\hline & 3 & 5,84 & 5,73 & 0,11 & Normal \\
\hline & 4 & 5,84 & 5,77 & 0,07 & Normal \\
\hline & 5 & 5,84 & 5,75 & 0,09 & Normal \\
\hline & 6 & 5,84 & 5,79 & 0,05 & Normal \\
\hline & 7 & 5,84 & 5,84 & 0 & Normal \\
\hline & 8 & 5,84 & 5,81 & 0,03 & Normal \\
\hline & 9 & 5,84 & 5,80 & 0,04 & Normal \\
\hline & 10 & 5,84 & 5,80 & 0,04 & Normal \\
\hline \multicolumn{2}{|l|}{ Rata-rata } & 5,84 & 5,78 & 0,06 & \\
\hline
\end{tabular}

Tabel di atas merupakan hasil pengambilan data pada larutan urin 2 yang dilakukan sebanyak 10 kali pengujian. Untuk nilai yang ditampilkan pada display LCD menunjukkan nilai atau angka keluaran yang tepat sesuai dengan indikasi sebenarnya berdasarkan nilai $\mathrm{pH}$ (normal $=5.5-7)$. Dari hasil pengujian didapatkan selisih tertinggi yaitu 0,11 pada percobaan ke 3 dan selisih terendah yaitu 0,02 pada percobaan ke-1. Untuk data hasil pengujian dengan hasil yang baik terdapat pada percobaan 7 karena hasil data yang didapat yaitu 5,84 sama dengan hasil pada alat pembanding. Dari hasil pengujian 10 kali tersebut didapatkan rata-rata yang pada alat yang dibuat adalah 5,78 dan alat pembanding 5,84 .

Adapun untuk tabel dan analisa hasil pengujian dapat dilihat pada Tabel 5 di bawah ini:

Tabel 5. Hasil Pengukuran Sampel 3 di Ruang Laboratorium Farmasi dan Farmakologi

\begin{tabular}{|c|c|c|c|c|c|}
\hline \multirow[b]{2}{*}{ Sampel } & \multirow[b]{2}{*}{ Percobaan } & \multicolumn{2}{|c|}{ Hasil Percobaan } & \multirow[b]{2}{*}{ Selisih } & \multirow[b]{2}{*}{ Indikator Hasi } \\
\hline & & $\mathrm{pH}$ meter & $\begin{array}{c}\text { Modul } \\
\text { Penelitian }\end{array}$ & & \\
\hline \multirow{10}{*}{$\begin{array}{l}\text { Larutan } \\
\text { urin } 3\end{array}$} & 1 & 5,51 & 5,39 & 0,12 & Normal \\
\hline & 2 & 5,51 & 5,37 & 0,14 & Normal \\
\hline & 3 & 5,51 & 5,45 & 0,06 & Normal \\
\hline & 4 & 5,51 & 5,51 & 0 & Normal \\
\hline & 5 & 5,51 & 5,48 & 0,03 & Normal \\
\hline & 6 & 5,51 & 5,45 & 0,04 & Normal \\
\hline & 7 & 5,51 & 5,40 & 0,11 & Normal \\
\hline & 8 & 5,51 & 5,47 & 0,04 & Normal \\
\hline & 9 & 5,51 & 5,56 & 0,05 & Normal \\
\hline & 10 & 5,51 & 5,52 & 0,01 & Normal \\
\hline \multicolumn{2}{|l|}{ Rata-rata } & 5,51 & 5,46 & 0,05 & \\
\hline
\end{tabular}

Tabel di atas merupakan pengambilan data pada larutan urin 3 yang dilakukan sebanyak 10 kali pengujian. Untuk nilai yang ditampilkan pada display LCD menunjukkan nilai atau angka keluaran yang tepat sesuai dengan indikasi sebenarnya berdasarkan nilai $\mathrm{pH}($ normal $=5.5-7)$. Dari hasil pengujian didapatkan selisih tertinggi yaitu 0,14 pada percobaan ke-2 dan selisih terendah yaitu 0,01 pada percobaan ke-10. Untuk data hasil pengujian dengan hasil yang baik terdapat pada

Medika Teknika : Jurnal Teknik Elektromedik Indonesia, Vol 01 No. 2, April 2020 | 40 
Fajrin, Zakiyyah, Supriyadi

Alat Pengukur pH Berbasis Arduino

percobaan ke 4 karena hasil data yang didapat yaitu 5,51 sama dengan hasil pada alat pembanding. Dari hasil pengujian $10 \mathrm{kali}$ tersebut didapatkan rata-rata yang pada $\mathrm{pH}$ meter yang dibuat adalah 5,46 dan alat pembanding 5,51.

Adapun untuk tabel dan analisa hasil pengujian dapat dilihat pada Tabel 6 di bawah ini: Tabel 6. Hasil Pengukuran Sampel 4 di Ruang Laboratorium Farmasi dan Farmakologi

\begin{tabular}{|l|l|l|l|l|l|}
\hline \multirow{2}{*}{ Sampel } & \multirow{2}{*}{ Percobaan } & \multicolumn{2}{|c|}{ Hasil Percobaan } & \multirow{2}{*}{ Selisih } & \multirow{2}{*}{ Indikator Hasil } \\
\cline { 3 - 6 } & & $\mathrm{pH}$ meter & Modul Penelitian & & \\
\hline \multirow{5}{*}{$\begin{array}{l}\text { Larutan } \\
\text { urin 4 }\end{array}$} & 1 & 7,00 & 6,89 & 0,11 & Normal \\
\cline { 2 - 6 } & 2 & 7,00 & 6,85 & 0,15 & Normal \\
\cline { 2 - 6 } & 3 & 7,00 & 6,89 & 0,11 & Normal \\
\cline { 2 - 6 } & 4 & 7,00 & 6,95 & 0,05 & Normal \\
\cline { 2 - 6 } & 7 & 7,00 & 6,88 & 0,12 & Normal \\
\cline { 2 - 6 } & 8 & 7,00 & 6,93 & 0,07 & Normal \\
\cline { 2 - 6 } & 9 & 7,00 & 6,97 & 0,03 & Normal \\
\cline { 2 - 6 } & 10 & 7,00 & 6,99 & 0,01 & Normal \\
\hline Rata-rata & 7,00 & 6,93 & 0 & Normal \\
\hline
\end{tabular}

Tabel di atas merupakan pengambilan data pada larutan urin 4 yang dilakukan sebanyak 10 kali pengujian. Untuk nilai yang ditampilkan pada display LCD menunjukkan nilai atau angka keluaran yang tepat sesuai dengan indikasi sebenarnya berdasarkan nilai $\mathrm{pH}$ (normal $=5.5-7$ ). Dari hasil pengujian didapatkan selisih tertinggi yaitu 0,15 pada percobaan ke-2 dan selisih terendah yaitu 0,01 pada percobaan ke-8. Untuk data hasil pengujian dengan hasil yang baik terdapat pada percobaan ke-9 karena hasil data yang didapat yaitu 7,00 sama dengan hasil pada alat pembanding. Dari hasil pengujian $10 \mathrm{kali}$ tersebut didapatkan rata-rata yang pada $\mathrm{pH}$ meter yang dibuat adalah 6,93 dan alat pembanding 7,00.

Berdasarkan pengambilan data yang telah dilakukan didapatkan uraian data hasil pengukuran yang dapat dilihat pada Tabel 7 di bawah ini:

Tabel 7. Uraian Data Hasil Pengukuran

\begin{tabular}{|l|l|l|l|}
\hline \multirow{2}{*}{ Percobaan } & \multicolumn{3}{|c|}{ Hasil Analisa Data } \\
\cline { 2 - 4 } & \multicolumn{1}{|c|}{ Rata-rata } & \multicolumn{1}{|c|}{ Simpangan } & \multicolumn{1}{c|}{ Error } \\
\hline 1 & 4,12 & 0,03 & $0,73 \%$ \\
\hline 2 & 6,80 & 0,08 & $1,09 \%$ \\
\hline 3 & 6,56 & 0,06 & $1,06 \%$ \\
\hline 4 & 5,78 & 0,06 & $1,02 \%$ \\
\hline 5 & 5,46 & 0,05 & $0,91 \%$ \\
\hline 6 & 6,93 & 0,07 & $1 \%$ \\
\hline
\end{tabular}

Dari pengujian yang telah dilakukan didapatkan hasil uraian data yang dapat dilihat pada Tabel 7 di atas. Pada tabel dapat dilihat uraian data hasil pengukuran berdasarkan hasil dari ratarata, simpangan, error. Dari hasil yang didapat masih dalam batas toleransi yaitu tidak lebih dari 5\% menurut standard IEC no.13B-23 [15]. Terdapat beberapa faktor yang mempengaruhi hasil yaitu dari sensor elektroda gelas itu sendiri, dimana kemampuan sensor membaca sampel yang tidak stabil mempengaruhi hasil yang diperoleh sehingga nilai yang didapat naik turun. Selain itu terdapat juga faktor dari modul sensor, dimana respon time dan waktu stabil modul penguat yang lambat juga mempengaruhi hasil yang didapat sehingga hasil yang didapat berbeda dengan alat pembanding.

Medika Teknika : Jurnal Teknik Elektromedik Indonesia, Vol 01 No. 2, April 2020 | 41 
Pada sub bab uraian ketahanan baterai ini akan menjelaskan mengenai daya tahan baterai yang digunakan. Pada $\mathrm{pH}$ meter ini terdapat display tegangan baterai pada seven segment yang digunakan untuk mengetahui sisa tegangan baterai yang masih ada. Adanya display tegangan baterai ini untuk mengantisipasi tegangan pada alat agar alat masih bisa bekerja dengan baik dan tidak mati pada saat sedang digunakan. Dalam hal ini alat menggunakan baterai dengan tegangan yang digunakan yaitu 3,7 volt dan untuk menyuplai semua rangkaian dibutuhkan tegangan sebesar 5 volt sehingga diperlukan modul step up yang digunakan untuk menaikan tegangan agar didapat tegangan 5 volt. Adapun untuk daya tahan baterai alat pada saat dioperasikan dan tidak dioperasikan dapat dilihat pada Tabel 8 di bawah ini:

Tabel 8. Data Pengukuran Ketahanan Baterai

\begin{tabular}{|c|c|c|c|c|}
\hline \multirow{2}{*}{ Waktu(menit) } & \multicolumn{2}{|c|}{ Dioperasikan } & \multicolumn{2}{|c|}{ Tidak Dioperasikan } \\
\hline & Awal & Akhir & Awal & Akhir \\
\hline \multirow{4}{*}{60 menit } & 3,97 & 3,84 & 3,97 & 3,92 \\
\hline & 3,84 & 3,71 & 3,92 & 3,87 \\
\hline & 3,71 & 3,58 & 3,87 & 3,82 \\
\hline & 3,58 & 3,45 & 3,82 & 3,77 \\
\hline
\end{tabular}

Pada tabel di atas dapat dilihat hasil ketahanan baterai yang diuji setiap \pm 60 menit pada saat alat dioperasikan dan tidak dioperasikan. Pada saat alat sedang dioperasikan mengalami penururan tegangan 0,13 volt setiap 60 menit dan alat mampu bertahan selama \pm 8 jam sementara pada saat alat tidak dioperasikan mengalami penurunan tegangan 0,05 volt setiap 60 menit dan alat mampu bertahan selama 3 hari. $\mathrm{pH}$ meter ini tidak dapat bekerja jika tegangan di bawah 3,10 volt. Untuk waktu pengisian baterai memerlukan waktu selama $\pm 2,5$ jam sampai baterai terisi penuh, dimana tegangan baterai jika penuh adalah 3,97 volt.

Dari hasil yang didapat terdapat beberapa faktor yang mempengaruhi penurunan baterai di antaranya pada modul sensor dan modul step up. Pada modul sensor ini terdapat konsumsi daya pada komponen sebesar $\leq 0,5 \mathrm{~W}$ dan bekerja pada saat arus 5-10 $\mathrm{mA}$ yang menyebabkan penurunan tegangan pada baterai. Selain itu pada modul step up yang digunakan juga menyebabkan tegangan berkurang. Sebab pada saat saklar alat posisi off rangkaian yang lain tidak mendapat supply tegangan baterai akan tetapi supply tegangan baterai tetap mengaliri modul step up. Inilah yang menjadi penyebab tegangan baterai berkurang meski alat tidak digunakan.

\section{KESIMPULAN}

Setelah melakukan proses pembuatan, percobaan, pengujian alat dan pendataan, penulis dapat menyimpulkan sebagai berikut:

a. Dapat dibuatnya alat $\mathrm{pH}$ meter yang dapat membantu user dalam melakukan pengujian dengan menggunakan Arduino Uno dan display LCD dengan penambahan indikator hasil $\mathrm{pH}$.

b. Berdasarkan pengambilan data yang telah dilakukan dengan menggunakan pembanding, didapatkan hasil error alat dengan nilai error di bawah 1,5\%.

\section{DAFTAR PUSTAKA}

[1] M. I. SARI, Fungsi Sistem Ginjal Dalam Homeostatis. Depok, 2007.

[2] E. Rizqyah Utami and D. Suyono, "THE EFFECT of GIVING KOMBUCHA TEA on STABILITY of BLOOD SERUM pH of Rattus norvegicus," UNESA J. Chem., vol. 1, no. 2, pp. 26-30, 2012.

[3] "Analisa Gas Darah.".

[4] Noorulil Bayu, "Rancang Bangun Model Mekanik Alat untuk Mengukur Kadar Keasaman

Medika Teknika : Jurnal Teknik Elektromedik Indonesia, Vol 01 No. 2, April $2020 \mid 42$ 
Fajrin, Zakiyyah, Supriyadi

Alat Pengukur pH Berbasis Arduino

Susu Cair, Sari Buah dan Soft Drink,” Teh. Kim., pp. 1-9, 2011.

[5] I. Tahir, Arti Penting Kalibrasi Pada Proses Pengukuran Analitik: Aplikasi Pada Penggunaan pH Meter dan Spektrofotometer UV. Yogyakarta: Universitas Gadjah Mada.

[6] F. Silvian, "pH Meter Digital," Surabaya, 2007.

[7] P. E. Pambudi, "Identifikasi Daging Segar dan Busuk Menggunakan Sensor Warna RGB dan PH Meter Digital," J. Teknol. Technoscientia, vol. 7, no. 1, pp. 46 - 53, 2014.

[8] N. Ketut and A. Aryanti, "Perencanaan dan Pembuatan Alat Kontrol pH Pada Kolam Pemebenihan Ikan Menggunakan FPAA," Inst. Teknol. Surabaya, pp. 1-6.

[9] D. Suherman, "Penerapan Logika Fuzzy Pada PLC Untuk Pengolahan Air Bersih ui Bak Penampungan PDAM Balikpapan," vol. II, pp. 1 - 7, 2012.

[10] F. Amani and K. Prawiroredjo, "Alat Ukur Kualitas Air Minum dengan Parameter Ph, Suhu, Tingkat Kekeruhan, dan Jumlah Padatan Terlarut," Jetri, vol. 14, no. 1, pp. 49-62, 2016.

[11] D. W. N. F. Astria and M. Subito, "Rancang Bangun Alat Ukur pH dan Suhu Berbasis Short Message," Metrik, vol. 1, no. 1, pp. 47-55, 2014.

[12] D. J. M. Y. A. Tuwaidan and V. C. Poekoel, "Rancang Bangun Alat Ukur Desibel (dB) Meter Berbasis Mikrokontr oler Arduino Uno R3," E-journal Tek. Elektro dan Komput., pp. 37-43, 2015.

[13] H. R. FAJRIN, N. R. TUHFA'TUN, and D. SUKWONO, "Perancangan Oxygen Analyzer Dilengkapi Penyimpanan Data Eksternal Berbasis Arduino Uno," ELKOMIKA J. Tek. Energi Elektr. Tek. Telekomun. Tek. Elektron., vol. 7, no. 3, p. 559, 2019.

[14] S. H. E. Ihsanto, "Rancang Bangun Sistem Pengukuran pH Meter Dengan Menggunakan Mikrokontroller Arduino Uno," Teknol. Elektro, Univ. Mercu Buana, vol. 5, no. 3, pp. 130137, 2014.

[15] J. Santosao, Alat Ukur dan Teknik Pengukuran. Jakarta: Departemen Pendidikan Nasional, 2008. 